\title{
ANALISIS EFEKTIVITAS KINERJA DAN KONTRIBUSI RETRIBUSI PEMAKAIAN KEKAYAAN DAERAH TERHADAP PENDAPATAN ASLI DAERAH
}

\author{
William J. Manuputty ${ }^{1}$, David P. E. Saerang ${ }^{2}$, Stanly W. Alexander ${ }^{3}$ \\ 1,2,3 Jurusan Akuntansi, Fakultas Ekonomi dan Bisnis Universitas Sam Ratulangi, Jl. Kampus Bahu, Manado, \\ 95115, Indonesia \\ E-mail : willj130996@gmail.com
}

\begin{abstract}
Retribution is one of the income obtained by various services given or certain permits by the government and one of the agencies that process it is BPPRD, in the North Sulawesi Province BPPRD there is acceptance of many types of retribution one of which is regional wealth usage retribution. The purpose of the authors in this study is to find out the effectiveness of performance and the contribution of retribution on the use of regional wealth in PAD which is a regional development resource analyzed by qualitative methods. The results obtained through this research are able to determine the effectiveness of regional wealth retribution for the past five years is very good in its realization with an average percentage $91,9 \%$ with its contribution to local revenue at 0,17\%.
\end{abstract}

Keywords : retribution, local revenue, performance efectivity

\section{PENDAHULUAN}

Perkembangan di indonesia saat ini tidak terlepas dari simber penerimaan pajak juga, dimana pajak dapat diandalkan untuk membiayai pembangunan nasional, sama halnya dengan retribusi yang sangat berpengaruh bagi pendapatan daerah. Pemerintah daerah povinsi sulawesi utara menerbitkan Perda No 7 Tahun 2011 tentang pajak dan Perda No 1 Tahun 2012 tentang retribusi sebagai dasar pemungutan.

Pada tahun 2017 sebagai dasar pengenanaan target PAD Sulut secara agresif mengalami penurunan relatif kecil sebesar $0,06 \%$.Turunnya target pajak daerah sebesar 3\% dari tahun 2016 ditutup dengan mendongkrak penerimaan asli daerah lainnya, seperti pajak daerah yang tumbuh sebesar $17,3 \%$ disbanding triwulan yang sama tahun 2016 dan retribusi yang naik $1 \%$ dari tahun sebelumnya provinsi sulut $44,9 \%$ dari target.

\section{TINJAUAN PUSTAKA}

Akuntansi. Dalam Accounting Priciple Board (APB), akuntansi adalah seni pencatatan, penggolongan dan pringkasan transaksi dan kejadian yang bersifat keungan dengan cara yang berdaya guna dan dalam bentuk satuan uang dan penginterprestasian hasil periode tersebut.

Akuntansi Perpajakan.Akuntansi pajak adalah penetapan seberapa besar pajak terutang melalui laporan keuangan perusahaan. Bidang akuntansi yang berkaitan dengan perhitungan perpajakan yang mengacu pada peraturan, udang undang dan aturan pelaksanaan perpajakn (Lestari, 2018:579).

Retribusi Daerah. Retribusi daerah sebagai pungutan daerah atas jasa atau pemberian izin tertentu yang diberikan oleh pemerintah daerah untuk kepentingan pribadi atau badan.

Jenis dan Tarif Retribusi Daerah.Dalam proses pemungutan retribusi daerah pemerintah daerah harus melakukan inventarisasi serta pengelompokan secara menyeluruh asset-asset milik daerah, dan menilai serta mengelola asset dengan penerapan manajemen asset terpadu dan secara terus menerus. 
Efektivitas. Merupakan penilaian yang dibuat sehubungan dengan prestasi individu, kelompok, dan organisasi.

Kinerja. Kinerja adalah sebuah prestasi kerja yang merupakan hasil atau tingkat keberhasilan seseorang atau organisasi dalam melaksanakan keseluruhan tugas dibandingkan dengan berbagai kemungkinan, seperti standar hasil kerja, target atau sasaran atau kriteria yang telah ditentukan terlebih dahulu dan disepakati bersama selama periode tertentu.

Kontribusi. Kontribusi adalah suatu hal yang diberikan bersama-sama bersama pihak lain untuk tujuan biaya atau kerugian tertentu.

Pendapatan Asli Daerah. Penghasilan yang didapatkan dari potensi-potensi dalam daerah yang diolah pemerintah daerah,dipungut berdasarkan peraturan daerah dan sesuai dengan peraturan perundang-undangan yang berlaku.

\section{METODE PENELITIAN}

Sumber Data. Sumber data yang digunakan oleh penulis dalam melakukan penelitian ini adalah data primer dan data sekunder. Adapun sumber data berupa hasil wawancara dan dokumentasi yang dilakukan secara langsung dengan kepala sub bidang retribusi bagian pemakaian kekayaan daerah di kantor BPPRD Provinsi Sulawesi Utara terkait dengan datadata yang diperlukan dalam penelitian.

\section{Metode Pengumpulan Data}

1. Wawancara. Wawancara yang dilakukan kepada Bidang pendapatan lain-lain sub bidang retribusi kantor BPPRD Provinsi Sulawesi Utara. Adapun pertanyaan yang akan ditanyakan adalah sebagai berikut:

a. Apa saja aspek yang dipertimbangkan dalam pemungutan retribusi pemakaian kekayaan daerah?

b. Pengenaan tarif dan perhitungan retribusi pemakaian kekayaan daerah?

c. Sistem pemungutan yang dipakai?

d. Upaya pemerintah terkait pemungutan serta penyetoran dan hasil perhitungan retribusi pemakaian kekayaan daerah?

2. Dokumentasi. Dokumentasi dilakukan dengan mengumpulkan dokumen-dokumen yang diperlukan dalam proses penelitian pada Badan Pengelola Pajak dan Retribusi Daerah Provinsi Sulawesi Utara seperti:

a. Laporan realisasi pendapatan asli daerah Provinsi Sulawesi Utara tahun 2013-2017.

b. Laporan Realisasi penerimaan retribusi Provinsi Sulawesi Utara tahun 2013-2017.

c. Laporan jumlah target retribusi pemakaian kekayaan daerah Provinsi Sulawesi Utara tahun 2013-2017.

d. Laporan realisasi penerimaan retribusi pemakaian kekayaan daerah Provinsi Sulawesi Utara tahun 2013-2017.

Metode dan Proses Analisis Data. Metode dan analisis data yang digunakan dalam penelitian ini adalah metode analisis deskriptif, yaitu menjelaskan efektivitas kinerja RPKD dan kontribusinya terhadap pendapatan asli daerah Provinsi Sulawesi Utara.

\section{HASIL PENELITIAN DAN PEMBAHASAN}

\subsection{Hasil Penelitian}

Aspek Nama, Objek dan Subjek. Setelah dilakukan wawancara yang dilakukan dengan pada ibu onaliske wehantouw yang menjabat sebagai kepala sub bidang retribusi daerah, dikemukakan bahwa pemungutan RPKD yang ada di sulawesi utara berasal dari fasilitas dan perangkat daerah.

Efektivitas Retribusi Pemakaian Kekayaan Daerah. Dengan menggunakan analisis ini kita akan mengetahui efektivitas dari RPKD Provinsi Sulawesi Utara pada tahun 2013 
samapai dengan 2017. Tingkat efektivitas retribusi pemakaian kekayaan daerah tahun 2015 adalah sebagai berikut :

$$
\text { Efektivitas }=\frac{1.840 .767 .433}{1.560 .500 .000} \times 100 \%=117,62 \%
$$

Tindakan Pemerintah Dalam Melakukan Audit Terkait Perhitungan, Pemungutan serta Penyetoran dan Sanksi Yang Diebrikan Atas Retribusi Pemakaian Kekayaan Daerah. Terkait dengan hal ini BPPRD beserta semua Perangkat Daerah Provinsi Sulawesi Utara memiliki sistem yang di terapkan yaitu pemeriksaan berkala setiap tahun yang dijalankan pemerintah melalui Inspektorat, Irjen dan BPK sehingga mulai dari proses pemungutan sampai penyetoran yang dilakukan serta menghitung hasil yang diperoleh dari retribusi pemakaian kekayaan daerah dilakukan dengan sistem yang terorganisasi dan akurat. Dalam proses penagihan diberikan surat teguran dengan jangka waktu, dikeluarkan oleh pejabat yang berwenang dengan ketetapan atau tata cara penagihan yang ada.

\subsection{Pembahasan}

Efektivitas Penerimaan Retribusi Pemakaian Pekayaan Daerah Provinsi Sulawesi Utara Tahun 2013-2017. Di bawah ini merupakan tabel efektivitas penerimaan retribusi pemakaian kekayaan daerah Provinsi Sulawesi Utara pada tahun 2013-2017.

Tabel 1. Efektivitas Penerimaan RPKD Provinsi Sulawesi Utara Tahun 2013-2017

\begin{tabular}{ccrrc}
\hline Tahun & $\begin{array}{c}\text { Target PBBKB } \\
(\mathbf{R p})\end{array}$ & $\begin{array}{c}\text { Realisasi PBBKB } \\
(\mathbf{R p})\end{array}$ & $\begin{array}{c}\text { Persentase } \\
(\boldsymbol{\%})\end{array}$ & Kriteria \\
\hline 2013 & 2.426 .444 .000 & 1.555 .657 .718 & $64,03 \%$ & Cukup fektif \\
2014 & 1.561 .100 .000 & 2.070 .441 .863 & $132,62 \%$ & Sangat Efektif \\
2015 & 1.560 .500 .000 & 1.840 .747 .433 & $117,96 \%$ & Sangat Efektif \\
2016 & 1.919 .350 .000 & 1.670 .700 .492 & 87,045 & Sangat Efektif \\
2017 & 2.197 .900 .000 & 1.293 .623 .873 & $58,85 \%$ & Tidak Efektif \\
& Rata-rata & & $91,9 \%$ & Sangat Efektif \\
\hline
\end{tabular}

Sumber: Data Hasil Olahan 2018

Pada tabel 1 di atas menunjukan dalam dua tahun terakhir penerimaan pendapatan melalui retribusi pemakaian kekayaan daerah terus mengalami penurunan, serta menunjukkan bahwa rata-rata penerimaan Provinsi Sulawesi Utara tahun 2013-2017 melalui retribusi ini ialah $91,9 \%$ yang berarti sangat efektif.

Kontribusi Penerimaan Retribusi Pemakaian Kekayaan Daerah Terhadap Pendapatan Asli Daerah Provinsi Sulawesi Utara tahun 2013-2017. Berikut ini merupakan tabel kontribusi penerimaan retribusi pemakaian kekayaan daerah terhadap pendapatan asli daerah Provinsi Sulawesi Utara pada tahun 2013-2017. 
Tabel 2. Kontribusi RPKD terhadap PAD Provinsi Sulawesi Utara

Tahun 2013-2017

\begin{tabular}{ccrrr}
\hline Tahun & $\begin{array}{c}\text { Realisasi PBBKB } \\
(\mathbf{R p})\end{array}$ & $\begin{array}{c}\text { Realisasi PAD } \\
(\mathbf{R p})\end{array}$ & $\begin{array}{c}\text { Persentase } \\
(\boldsymbol{\%})\end{array}$ & Kriteria \\
\hline 2013 & 1.555 .657 .718 & 785.467 .967 .366 & $0,19 \%$ & Kurang Berkontribusi \\
2014 & 2.070 .441 .863 & 938.583 .020 .354 & $0,22 \%$ & Cukup Berkontribusi \\
2015 & 1.840 .747 .433 & 1.012 .945 .961 .386 & $0,18 \%$ & Cukup Berkontribusi \\
2016 & 1.670 .700 .492 & 981.044 .550 .486 & $0,17 \%$ & Kurang Berkontribusi \\
2017 & 1.293 .623 .873 & 981.235 .631 .829 & $0,13 \%$ & Cukup Berkontribusi \\
& Rata-rata & & $0,17 \%$ & Cukup Berkontribusi \\
\hline
\end{tabular}

Sumber: Data Hasil Olahan 2018.

Tabel 2 yang berisi tentang informasi realisasi PAD dan realisasi retribusi pemakaian kekayaan daerah dari tahun 2013-2017 memiliki presentasi rata-rata tidak melebihi 1\% dari hasil realisasi PAD di Provinsi Sulawesi Utara, berdasarkan hasil tersebut bisa disebutkan bahwa nilai kontribusi retribusi ini masih sangat kurang. Dengan hasil perolehan 2.070.441.863 pada tahun 2014 yang menjadi angka pendapatan tertinggi selama lima tahun terakhir dengan presentase kontribusi 0,22\% dari PAD yang berjumlah 938.583.020.354, kemudian pada tahun berikutnya realisasi retribusi ini menurun dengan jumlah 1.840.767.433 sedangkan PAD yang dicapai pada tahun itu meningkat dari tahu sebelumnya sebesar 1.012.945.961.386 dan pada tahun 2016 dan 2017 realisasi RPKD terus menurun hingga angka 1.293.623.873 dengan presentase kontribusi hanya $0,13 \%$ dari pendapatan asli daerah tahun 2017 berjumlah 981.235.631.829.

\section{KESIMPULAN DAN SARAN}

\subsection{Kesimpulan}

Dengan memahami hasil penelitian dan pembahasan pada bab sebelumnya, penulis mengambil kesimpulan bahwa :

1. Dengan hasil nilai keefektifan $91,9 \%$ selama rata-rata lima tahun terkahir pemungutan retribusi pemakaian kekayaan daerah sebagai salah satu retribusi di Provinsi Sulawesi Utara sudah sangat efektif sehingga bisa menjadi salah satu penunjang pendapatan daerah.

2. Presentase kontibusi retribusi pemakaian kekayaan daerah terhadap pendapatan asli daerah sangatlah minim yang tidak mencapai angka $1 \%$ dalam lima tahun terakhir realisasi dari retribusi ini memilik nilai tertinggi sebesar 2.070.441.863 pada tahu 2014 dengan presentase $0,22 \%$ dibandingkan dengan jenis retribusi lain yang ada di Provinsi Sulawesi Utara retribusi pemakaian kekayaan daerah berada ditempat ketiga.

\subsection{Saran}

Setelah memperoleh hasil dan menarik kesimpulan melalui penelitian yang dilakukan, penulis ingin memeberikan saran yaitu :

1. Dilakukannya evaluasi perda tentang RPKD supaya tarif yang ada bisa diperbaharui sesuai dengan perkembangan perekonomian di daerah setiap tahun.

2. Pemberian sanksi sesuai aturan yang berlaku kepada wajib retribusi yang tidak memenuhi kewajibannya, berupa denda administrasi. 


\section{DAFTAR PUSTAKA}

Christianty, Paramita Lea. 2016. The analysis of the effectiveness and contribution of regional retribution towards own-source revenue (osr). Jurnal Unwidha. Vol 6,No 4, Hal 249 (2016).

Darmi, Titi. 2018.Locally-Generated Revenue As Capacity Parameters Of New Regional Autonmy Management. JKAP (Jurnal Kebijakan Dan Administrasi Publik) Vol 22,No 1, Hal 4 (2018).

Diterjemahkan oleh Ninuk Adriani. Binarupa Aksara. Jakarta.

Dunia, Firdaus A. 2013. Pengantar Akuntansi. Edisi 3. Penerbit: FE-UI. Jakarta.

Halim, Abdul. 2004. Akuntansi Keuangan Daerah Edisi Revisi. Penerbit: SalembaEmpat. Jakarta.

Luthadia, Anggre. 2016. Kontribusi Retribusi Pemakaian Kekayaan Daerah (RPKD) terhadap Penerimaan Kas Pendapatan Asli Daerah (PAD) Unit Pelaksana Teknis (UPT) Dinas Pendapatan Provinsi Jawa Timur Nganjuk. Tugas Akhir Program Studi Manajemen Universitas Gadjah Mada. Yogyakarta.

Syarpati, Wiwid Migi. 2016. Efektivitas Dan Kontribusi Penerimaan Retribusi Pemakaian Kekayaan Daerah Terhadap Pendpatan Asli Daerah. Journal Feb Unmul Vol 1,No 1,Hal 1-8 (2016). 